\title{
Continuity Trumps Change: The First Year of Trump's Administrative Presidency
}

Rachel Augustine Potter, University of Virginia

Andrew Rudalevige, Bowdoin College

Sharece Thrower, Vanderbilt University

Adam L. Warber, Clemson University

ABSTRACT From campaign rhetoric to tweets, President Trump has positioned himself as "disrupter in chief," often pointing to administrative action as the avenue by which he is leaving a lasting mark. However, research on the administrative presidency begins with the premise that all presidents face incentives to use administrative tools to gain substantive or political traction. If, as this article suggests, Trump's institutional standing differs little from his recent predecessors, then how much of the Trump presidency represents a change from past norms and practices? How much represents continuity, or the perennial dynamics of a far-from-omnipotent executive in an ongoing world of "separate institutions sharing powers" (Neustadt 1990, 29)? To answer this, we tracked presidential directives and regulatory policy during Trump's first year in office. We found evidence of continuity, indicating that in its use of administrative tactics to shape policy, the Trump White House largely falls in line with recent presidencies.

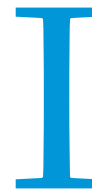

n May 2018, President Donald J. Trump tweeted: "We have had the most successful first 17-month Administration in US history-by far!" (Trump 2018). His claim rested on an embrace of the tools of the "administrative presidency," encompassing executive actions to advance presidents' policy preferences outside the legislative process (Rudalevige 2018). By December 2017, observers already agreed that Trump's various administrative tactics were crucial in evaluating his success in office. For instance, Politico highlighted " 138 things Trump did this year when you weren't looking," centering on regulatory policy (Vinik 2017).

To hear the White House tell it, Trump's unilateralism was new-and newly effective. At the 100-day mark, the press office asserted that, thanks to his executive orders (EOs), "President Trump has accomplished more in his first 100 days than any other

Rachel Augustine Potter iD is assistant professor of politics at the University of Virginia. She can be reached at rapotter@virginia.edu.

Andrew Rudalevige is the Thomas Brackett Reed Professor of Government at Bowdoin

College. He can be reached at arudalev@bowdoin.edu.

Sharece Thrower is assistant professor of political science at Vanderbilt University. She can be reached at sharece.d.thrower@vanderbilt.edu.

Adam L. Warber iD is professor of political science at Clemson University. He can be reached at awarber@clemson.edu. president since Franklin Roosevelt"1; the White House website devoted considerable space to a section it labeled "Presidential Actions." Pundits on the left and the right agreed on the scale of the change. But one side of the aisle praised its implications for "Deregulation nation!" whereas the other decried a "double-plus imperial presidency" (Drum 2018; Jones 2018).

This ostensibly aggressive approach to unilateralism in his first 100 days is consistent with numerous predictions of a marked change in administrative action under Trump. Given his unprecedented rhetoric on the campaign trail and his boisterous personality, many commentators described Trump as "disrupter in chief," a moniker that suggested his administrative presidency was a clear break from the norms and patterns of past administrations.

Theories of unilateral action, however, offer competing predictions for continuity (i.e., continuing the patterns of prior administrations). All presidents, not only Trump, are tempted by unilateral action: it offers a "first-mover" advantage that reduces internal transaction costs and bypasses collective action problems (Belco and Rottinghaus 2017; Moe and Howell 1999). Unilateralism promises quick and decisive action as well as the chance to short-circuit tedious parliamentary procedures, and it directly transforms presidential preferences into public policy on a widely publicized platform. Given that he faces the same incentives 
and constraints as any other modern president, Trump's actions should align with a constellation of factors that past research associates with augmented unilateral activity, including unified government, a pliable Congress, and a transition in power between administrations from one party to the other (Chiou and Rothenberg 2017; Howell 2003). ${ }^{2}$ From this institutional perspective, Trump's first year should look no different than that of any other modern president.

Did Trump's use of policy tools from his administrative arsenal represent a clear departure from previous presidential behavior or more of the same? In this brief article, we give this question the compliment of empirical scrutiny. We catalog and evaluate Trump's use of administrative mechanisms during his first year in office, assessing how his actions compare to those of recent presidents and to theoretical predictions about the administrative presidency. Specifically, if continuity prevails, we expect Trump to apply the tools of the administrative presidency in roughly the same manner as his predecessors: that is, at approximately the same volume and geared toward accomplishing similar ends. If, instead, change prevails, Trump should apply these tools in new ways, geared toward decidedly different ends or with a marked discontinuity in the number of executive actions produced.

Evaluating whether Trump's presidency falls into the category of "continuity" or "change" is not a cut-and-dried exercise, even along this single discrete dimension. However, we provide data on a number of discrete presidential actions to assess Trump's first-year's policy actions along with those of contemporary administrations dating back to the Reagan presidency. Given space constraints, we focus on executive action in two key areas: the use of assorted presidential directives and the administration's efforts toward regulatory relief. Our analysis is intentionally circumscribed to cover formal written actions, which are both important policy documents and comparable across administrations. 3 To preview, our findings suggest that continuity trumps change-although Trump's deregulatory efforts may prove to be disruptive in the longer term. the law. Between 1862 and the end of the Obama administration, presidents issued 13,764 numbered EOs.

Trump issued 55 EOs during his first year (figure 1). This was more first-year orders than Obama (39) and, indeed, more than each president since Reagan, with the exception of Clinton (who issued 57). However, raw numbers are only part of the story. As important, Trump used EOs in his inaugural year in much the same way as previous presidents-for similar purposes and on familiar issues.

For instance, about $38 \%$ of Trump's EOs dealt with government operations, including reordering the line of succession within agencies, creating advisory councils, requiring ethics pledges, and seeking to roll back federal regulations. Presidents commonly use EOs for such governmental purposes, ranging from $40 \%$ to $61 \%$ of presidents' orders since Reagan. Likewise, Trump issued numerous EOs related to foreign policy, defense, and national security $(25 \%)$. Again, so did his predecessors. Unlike earlier presidents, a greater share of Trump's national security orders dealt with immigration. For instance, he requested that agencies develop plans to build a wall bordering Mexico and to tighten enforcement of immigration laws. Most infamously, he ordered a travel ban on immigrants from certain countries.

New presidents also use EOs to revoke, amend, or supersede past presidents' policies. Trump revoked more EOs in his first year than Obama-but fewer than Reagan, Clinton, and George W. Bush (figure 2). Other presidents amended EOs far more frequently than Trump (i.e., Reagan issued 26 amendments, compared to Trump's three). Thus, Trump's modifications to earlier EOs were modest compared to other presidents.

When Trump did change past orders, his main target wasunsurprisingly-his immediate predecessor. For instance, he eliminated Obama's requirements for workplace protections for employees of federal contractors and for labor-management forums, as well as Obama's constraints on local law enforcement and efforts at emergency preparedness. Yet, this pattern is consistent with the actions of every other modern first-year president

\section{Did Trump's use of policy tools from his administrative arsenal represent a clear departure from previous presidential behavior or more of the same?}

\section{TRUMP'S UNILATERAL DIRECTIVES}

Although "executive order" is popular shorthand for any presidential directive, it is imprecise at best. Here, we inventory a more complete series of Trump's directives: executive orders (EOs), memoranda, proclamations, and signing statements, and we evaluate whether their use is closer to continuity or to change. It is worth noting at the outset that the content of these directives is as important as their count; we seek to assess both.

\section{Executive Orders}

EOs are the most salient form of presidential directive: they appear in the Federal Register and their formulation normally is guided by a standardized process of central clearance through the Office of Management and Budget (Rudalevige 2012). They may structure institutions and governmental advisory processes, delegate presidential powers or tasks, prod the development of future action, or direct executive branch officials on how to implement
(Thrower 2017). Many of Obama's labor EOs targeted by Trump were reversals of policies ordered by George W. Bush.

\section{Presidential Memoranda}

Another presidential directive, one increasingly used as a substitute for EOs, is the presidential memorandum (Lowande 2014). Like EOs, "memo orders" (cf. Woolley and Peters 2017) are used to shape policy implementation and prod agency action; they also may serve a public-relations purpose. Unlike EOs, their publication is not required and they have little jurisprudential history. One imperfect distinction is that EOs use presidential powers directly, whereas memoranda call on agencies to use their own authority to act in ways that a president desires.

Trump issued 41 memoranda in his first year-a relatively high number compared to recent presidents but fewer than Obama (45). The majority (59\%) of Trump's memos related to foreign policy, defense, and national security-higher than most contemporary 
Figure 1

Executive Orders and Memoranda by Presidents in their First Year

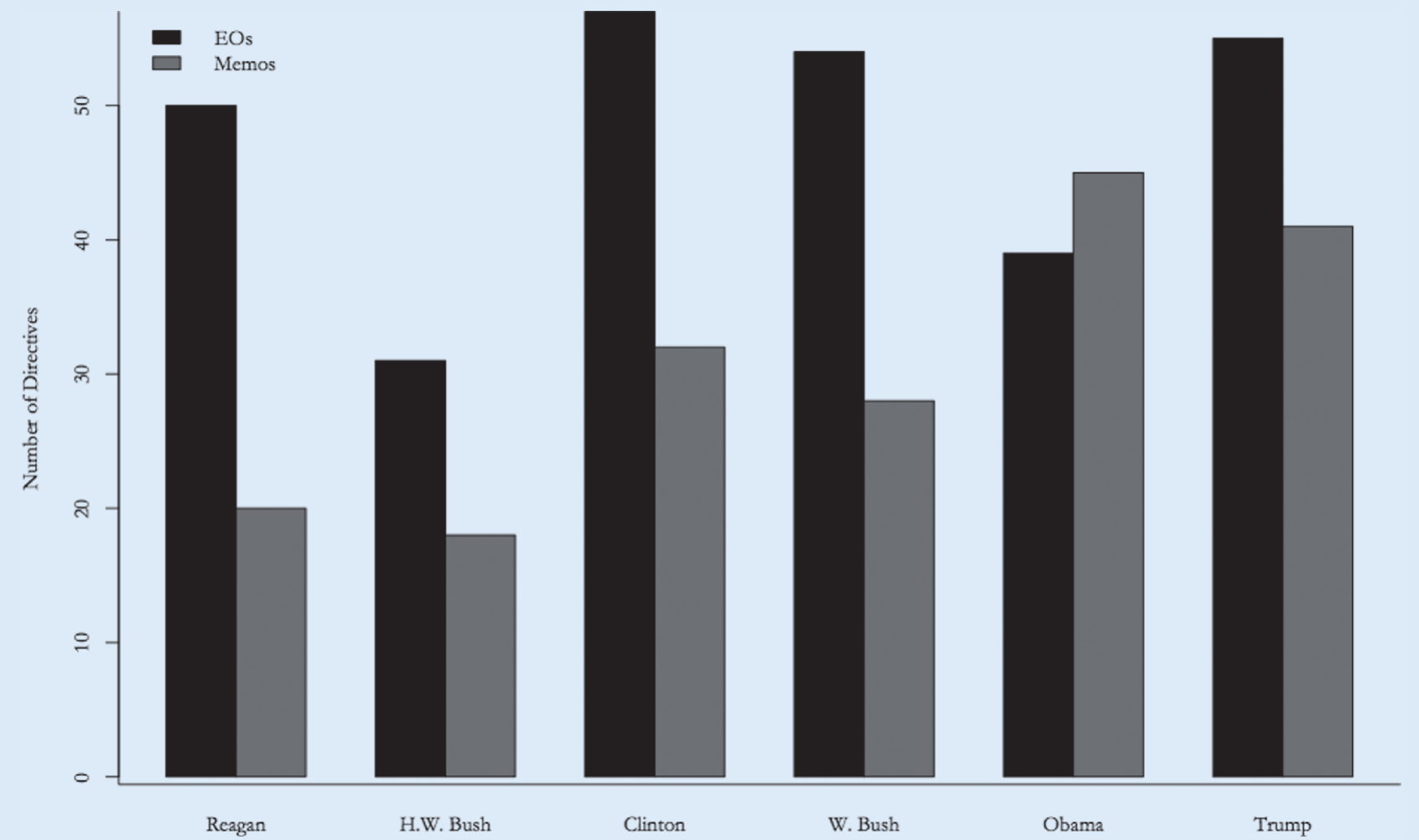

Source: Calculated from the American Presidency Project.

\section{Figure 2}

Executive Order Alterations by Presidents in their First Year

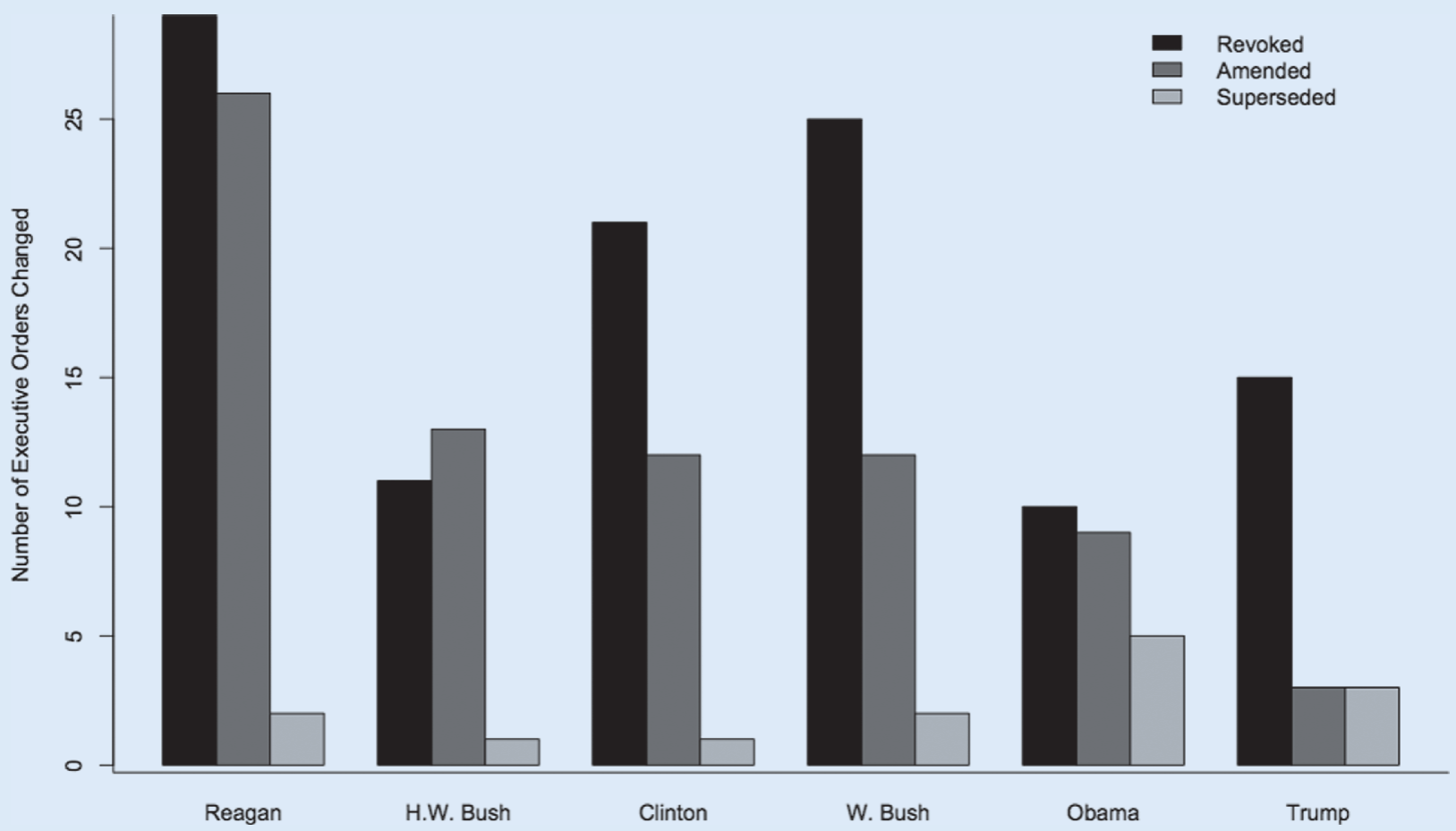


presidents (i.e., $20 \%$ for Reagan; $44 \%$ for George H. W. Bush; $31 \%$ for Clinton; and 29\% for Obama); however, George W. Bush, at $57 \%$, was comparable. These included some of Trump's more notable memoranda: withdrawing from the Trans-Pacific Partnership, restricting Obama's new openings to Cuba, and encouraging a transgender military ban. Overall, Trump's use of memoranda was largely in line with previous presidents': he called on agencies to prioritize new programs, study the effects of others, and investigate lawful means of implementing his preferences. In one case, he joined a long game of partisan "ping pong," using his first memo to reinstate (and somewhat broaden) the so-called Mexico City Policy, which bans federal funding to international organizations that provide information on abortion. This ban has been imposed by every Republican president and reversed by every Democrat president since Reagan. issued as a proclamation rather than an EO (Trump 2017b).4 In December 2017, Trump issued two proclamations reducing the size of two national monuments in Utah (Trump 2017c, 58081). Still, the monuments had been created by Obama and Clinton, respectively, using proclamations of their own. Indeed, prior presidents-including Taft, Wilson, Franklin Roosevelt, Truman, and Eisenhower-also used proclamations to downsize monuments, which reinforces the notion that Trump's actions suggest continuity (Dodds 2013).

\section{Signing Statements}

Although first used by James Monroe, signing statements have recently become notorious as a unilateral policy weapon. Issued when presidents sign an enrolled bill into law, such statements at times are merely remarks taking credit for the new statute or

\section{Overall, Trump's use of memoranda was largely in line with previous presidents': he called on agencies to prioritize new programs, study the effects of others, and investigate lawful means of implementing his preferences.}

\section{Proclamations}

At first glance, proclamations appear to be benign: ceremonial pronouncements that highlight occasions such as National Safe Boating Week (proclaimed on May 19, 2017). However, presidential history is littered with more substantive examples, from the Neutrality Proclamation of 1793 , to the Emancipation Proclamation seven decades later, to proclamations of emergency during the civil rights movement in the 196os (Belco and Rottinghaus 2017). A proclamation can take the form of a major policy statement directed toward the general public (unlike EOs and memoranda, which are directed to the executive branch) "that states a condition, declares the law and requires obedience, recognizes an event, or triggers the implementation of a law (by recognizing that the circumstances requiring action have been realized)" (Cooper 2014, 172).

Here, too, Trump followed in his predecessors' footsteps, in both volume (figure 3) and substance. He signed 119 proclamations during his first year, as did Clinton; Obama signed 127 and George H. W. Bush signed 149. George W. Bush lagged slightly at 114 and Reagan issued the fewest (72).

As expected, Trump issued a variety of ceremonial proclamations. Whereas many were boilerplates also issued by previous administrations, others aimed to underscore his policy agenda, ranging from the promotion of school choice to addressing the nation's crumbling infrastructure. His first proclamation, signed on January 20, 2017, declared that his inauguration would be a "National Day of Patriotic Devotion" (Trump 2017a).

Like previous presidents, Trump used proclamations to address significant policy areas, including immigration, the environment, and foreign policy. His third version of the travel ban-the first two were derailed by litigation-was praising key legislators for its success. However, statements also allow presidents to express objections to specific sections within a statute or to identify parts of a law that they might refuse to administer. Reagan was the first to systematically use signing statements in the hope of affecting the policy process-for instance, as part of a bill's legislative history for courts to consider (Kelley 2006, 75-79). George W. Bush demonstrated even greater interest and "issued more than 1,00o constitutional challenges to provisions in more than 150 laws during his first six years in office" (Thurber and Tama 2018, 91).

During his first year, Trump issued only seven signing statements, fewer than most of his recent predecessors (figure 4). This was on par with Obama's eight but well below the totals for Reagan (19), George H. W. Bush (43), Clinton (33), and George W. Bush (24). Indeed, it was the fewest since Harry Truman issued six in 1945.

\section{Figure 3 \\ Proclamations by Presidents in their First Year}

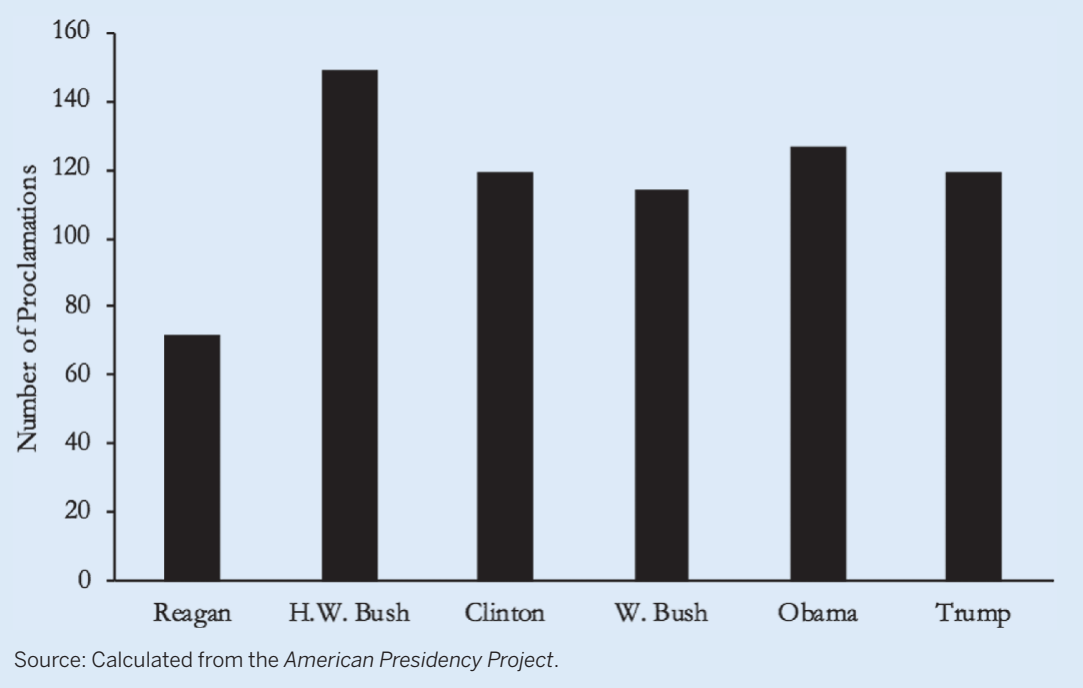


However, the raw number also may be misleading because it does not account for the substance of these actions. 5 Of the seven signing statements issued in 2017 , five raised constitutional concerns about specific areas of the law. The first Trump signing statement, issued on May 5 with the Consolidated Appropriations Act of 2017, singled out 75 of its provisions as being vague or constitutional violations. Thus, he used signing statements fairly aggressively to shape the interpretation, direction, and implementation of policy in federal laws. Again, however, this was in keeping with the practices that George W. Bush had established.

\section{TRUMP AND FEDERAL REGULATION}

Regulation typically is not considered a unilateral administrative power of the presidency because rules are written not by presidents but rather by bureaucrats. Still, regulation is a key aspect of the administrative state and, in his first year, Trump made regulationor, more specifically, deregulation-a key part of his agenda. $\mathrm{He}$ differed from recent presidents (even Republican presidents), who used regulations to advance other policy priorities on their agenda. Instead, channeling Reagan's deregulatory ethos, Trump pursued shrinking the number of existing regulations as a goal in its own right.

Within days of assuming office, Trump promised to repeal " $75 \%$, maybe more" of existing federal regulations. He pursued this agenda using several of the aforementioned tools of the in proposed rules under Trump suggests that agencies avoided issuing new rules altogether. Indeed, only eight significant proposed rules issued in 2017 (i.e., 10.7\% of the total) were identified as being explicitly deregulatory under Trump's new order. ${ }^{8}$ This may be evidence of a deterrent effect of the "2-for-1" order. A majority of regulatory actions issued in the first year were exempt from the order (Bolen 2017), suggesting that agencies withheld new proposals that otherwise would have been subject to the order.

Trump's deregulatory agenda met greater success in areas where the barriers to repeal were lower, such as in eliminating or modifying agency guidance and policy documents. For example, within one month of Trump assuming office, the Department of Education and the Department of Justice rescinded an Obama-era statutory interpretation that offered protections for transgender students in selecting bathrooms. Similar changes were made to guidance implementing the Affordable Care Act. Trump also delayed implementation of several economically significant rules from the Obama years (Thrower 2018).

In short, although Trump's deregulatory efforts in the first year were splashy, they did not meaningfully move the deregulatory needle. 9 Many high-profile actions, such as deregulatory orders, require long-term follow-through by agencies to be realized; it is not clear whether the political will for these actions can be sustained. Other non-regulatory policy actions are not necessarily durable because they are either temporary or can be readily

\section{These actions spurred considerable media buzz but were far from self-implementing. Trump's directives did not directly rescind regulations; instead, they ordered agencies to investigate the feasibility of repeal.}

administrative presidency. ${ }^{6}$ Most notably, he issued EO 13,771 to institute a "2-for-1" policy, whereby each new regulation issued by a federal agency had to be offset by the elimination of two existing ones. Trump also signed several memoranda and EOs directed at removing specific regulations.

These actions spurred considerable media buzz but were far from self-implementing. Trump's directives did not directly rescind regulations; instead, they ordered agencies to investigate the feasibility of repeal. This prolonged the process and left room for implementation "hiccups," which inevitably followed in several high-profile instances.7 Even to the extent that these orders accomplished deregulatory goals, they were targeted at individual rules and, therefore, piecemeal.

How successful was Trump in systematically rolling back existing regulations? Certainly, agencies issued fewer new proposed rules, including significant ones, during Trump's first year than that of George W. Bush and Obama (figure 5). However, this is not evidence of deregulation per se. Repealing regulations typically requires agencies to go through the noticeand-comment process, meaning that there should be more rather than fewer proposed rules in an era of deregulation. Instead, the decline undone by the next administration. In this sense, Trump has not successfully broken from the regulatory practices of past administrations; in other words, we see continuity. Where Trump may have made a lasting mark, however, is in stemming the tide of new regulatory burdens.
Figure 4
Signing Statements by Presidents in their First Year

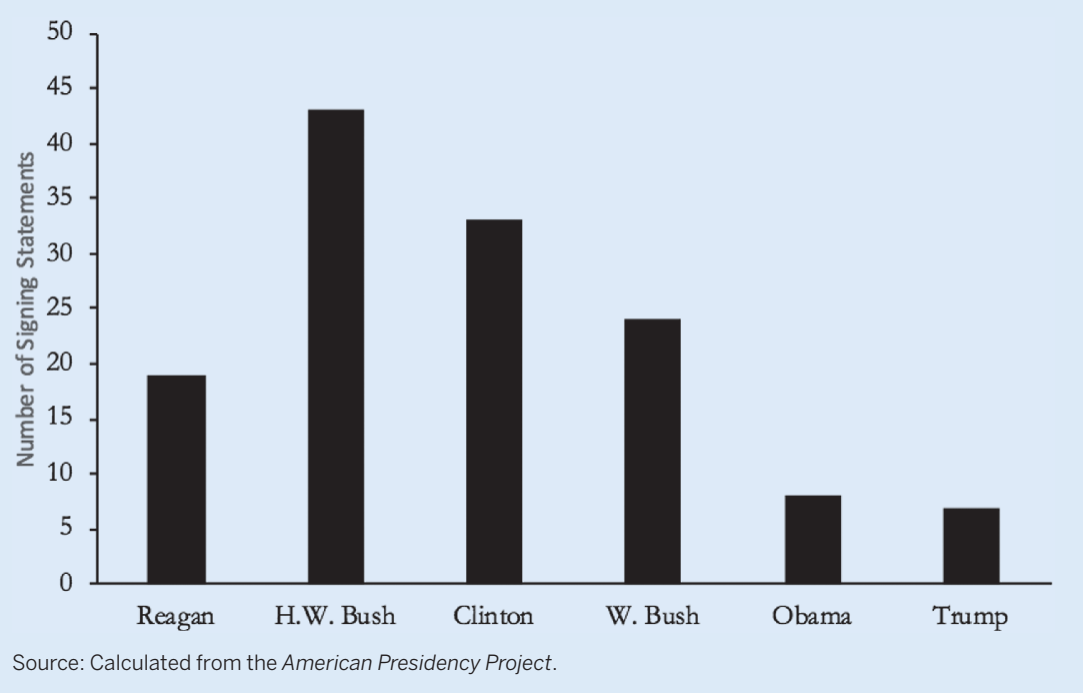


Figure 5

Proposed Rules Issued During the President's First Year

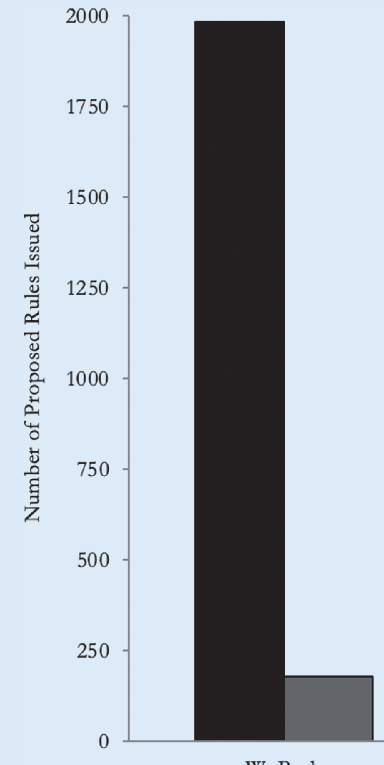

W. Bush
All Proposed

$\square$ Significant Proposed

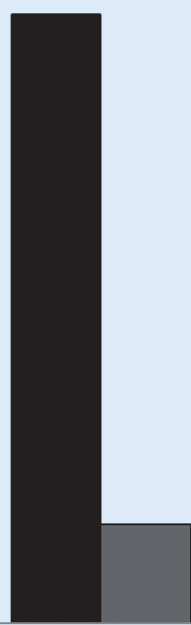

Obama

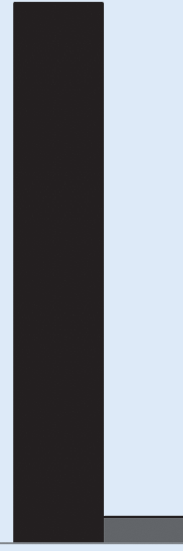

Trump

Source: Calculated from the Federal Register

Note: Proposed rule counts for cabinet agencies include the Environmental Protection Agency. Significance is as indicated by the agency in the Unified Agenda.

2. Prior research suggests that each of these factors is important in predicting administrative action by a new president. What we evaluate here is not whether the type of upswing that this literature might predict occurred but rather whether an incommensurate break transpired of the magnitude suggested by many media accounts and by Trump himself.

3. There certainly are other features of unilateralism that we could consider, such as centralization and politicization. However, these tools are in a different category from those studied here and are covered elsewhere in the literature (e.g., Lewis, Bernhard, and You 2018).

4. This was in accordance with the text of the Immigration and Nationality Act.

5. It is also worth noting that, given the low level of legislative productivity during his first year, Trump may have had fewer opportunities to issue signing statements (Schier and Eberly 2017, 65-66).

6. In Trump's first year, 16 high-profile regulations were rolled back under the Congressional Review Act. We do not discuss those actions because they applied to a small subset of rules and were accomplished in concert with Congress.

7. The Department of Labor's Fiduciary rule and the Environmental Protection Agency's Waters of the United States rule are two such examples.

8. Figures determined from each proposed rule's published "EO 13,771" declaration. Prior administrations did not report on the deregulatory status of rules.

9. Recent work has begun to explore the ways that presidents might use the Office of Information and Regulatory Affairs to pursue deregulation (Haeder and Yackee 2018).

\section{CONCLUSION: CONTINUITY TRUMPS CHANGE}

Despite efforts to chart a new course in American politics, the Trump White House continues to largely fall in line with recent presidencies regarding development of an administrative strategy to shape the policy process. This story played out in Trump's first year with the number and types of EOs, memoranda, proclamations, and signing statements that he issued. One area that sets Trump apart is his use of administrative tools to promote deregulation. Whereas all recent presidents have used these tools to manage the regulatory process, the scale on which Trump used them and the centrality of deregulation to his agenda were noteworthy-although not yet "written in stone."

Stepping back, the impact that these policy actions will have on the direction of future policy is unclear. For example, deregulating requires sustained effort because it can take years for agencies to undergo the process of removing rules from the books. The courts also will have an important role in checking Trump's agenda (Heinzerling 2018): his most controversial orders on immigration and the environment received significant pushback from the courts and, similarly, environmental groups have sued over his use of proclamations to scale back national monuments. Any president can sign a presidential directive with great flourish or announce the issuance of new regulations. However, such policy statements are not self-executing and they require a committed administration and a cooperative bureaucracy to ensure durable policy change. Given these impediments, continuity seems likely to prevail.

\section{NOTES}

1. Trump was said to have issued more EOs in his first 100 days than every president from Harry Truman onward-a claim that is accurate if counting from January 1949 but not from April 1945, when Truman first took office.

\section{REFERENCES}

Belco, Michelle, and Brandon Rottinghaus. 2017. The Dual Executive: Unilateral Orders in a Separated and Shared Power System. Stanford, CA: Stanford University Press.

Bolen, Cheryl. 2017. "Trump's 2-for-1 Regulatory Policy Yields Minimal Results.” Bloomberg News, September 29. Available at www.bna.com/trumps-2for1regulatory-n73014470324.

Chiou, Fang-Yi, and Lawrence S. Rothenberg. 2017. The Enigma of Presidential Power: Parties, Policies, and Strategic Uses of Unilateral Action. New York: Cambridge University Press.

Cooper, Phillip J. 2014. By Order of the President: The Use and Abuse of Executive Direct Action, 2nd edition. Lawrence: University Press of Kansas.

Dodds, Graham G. 2013. Take Up Your Pen: Unilateral Presidential Directives in American Politics. Philadelphia: University of Pennsylvania Press.

Drum, Kevin. 2018. "Donald Trump and the Double-Plus Imperial Presidency." Mother Jones, June 4. Available at www.motherjones.com/kevin-drum/2018/o6/ donald-trump-and-the-double-plus-imperial-presidency.

Haeder, Simon F., and Susan Webb Yackee. 2018. "Presidentially Directed Change: The Office of Information and Regulatory Affairs as Partisan or Moderator?" Journal of Public Administration Research and Theory 28 (4): 475-88.

Heinzerling, Lisa. 2018. “Trump Is Losing his War on Regulations.” Washington Post, March 27. Available at www.washingtonpost.com/opinions/trump-is-losinghis-war-on-regulations/2018/o3/27/82od 59da-1e61-11e8-ae5a-16e6oe46o5f story.html?noredirect $=$ on\&utm_term $=. d 2 \mathrm{ce} 74135 \mathrm{cbd}$.

Howell, William G. 2003. Power without Persuasion: The Politics of Direct Presidential Action. Princeton, NJ: Princeton University Press.

Jones, Terry. 2018. "Deregulation Nation: President Trump Cuts Regulations at Record Rates." Investors' Business Daily, August 14. Available at www.investors. $\mathrm{com} /$ politics/commentary/ deregulation-nation-president-trump-cuts-regulationsat-record-rate.

Kelley, Christopher S. (ed.). 20o6. Executing the Constitution: Putting the President Back into the Constitution. New York: SUNY Press.

Lewis, David E., Patrick Bernhard, and Emily You. 2018. "President Trump as Manager: Reflections on the First Year." Presidential Studies Quarterly 44 (3): 480-501.

Lowande, Kenneth. 2014. "After the Orders: Presidential Memoranda and Unilateral Action." Presidential Studies Quarterly 44 (4): 724-41.

Moe, Terry M., and William G. Howell. 1999. "The Presidential Power of Unilateral Action." Journal of Law, Economics and Organization 15 (1): 132-79. 
Neustadt, Richard E. 1990. Presidential Power and the Modern Presidents. New York: Free Press.

Rudalevige, Andrew. 2012. "Executive Orders and Presidential Unilateralism." Presidential Studies Quarterly 42 (1): 138-6o.

Rudalevige, Andrew. 2018. "The Presidency and Unilateral Power: A Taxonomy." In The Presidency and the Political System, 11th edition, ed. Michael Nelson, 477-503. Washington, DC: Sage/CQ Press.

Schier, Steven E., and Todd E. Eberly. 2017. The Trump Presidency: Outsider in the Oval Office. Lanham, MD: Rowman \& Littlefield.

Thrower, Sharece. 2017. “To Revoke or Not Revoke?: The Political Determinants of Executive Order Longevity." American Journal of Political Science 61 (3): $642-56$.

Thrower, Sharece. 2018. "Policy Disruption through Regulatory Delay in the Trump Administration.” Presidential Studies Quarterly 48 (3): 517-36.

Thurber, James A., and Jordan Tama (eds.). 2018. Rivals for Power: PresidentialCongressional Relations. Lanham, MD: Rowman \& Littlefield.
Trump, Donald J. 2017a. "National Day of Patriotic Devotion." Proclamation 9570. Federal Register 82 (14): 8349

Trump, Donald J. 2017b. "Enhancing Vetting Capabilities and Processes for Detecting Attempted Entry into the United States by Terrorists or Other Public-Safety Threats." Proclamation 9645. Federal Register 82 (186): 45161-72.

Trump, Donald J. 2017c. "Modifying the Bears Ears National Monument." Proclamation 9681. Federal Register 82 (235): 58081-87.

Trump, Donald J. (real DonaldTrump). 2018. "Despite the disgusting, illegal and unwarranted Witch Hunt, we have had the most successful first 17-month Administration in US history-by far! Sorry to the Fake News Media and 'Haters,' but that's the way it is!" May 17, 6: 52 a.m. Tweet.

Vinik, Danny. 2017. “138 Things Trump Did This Year When You Weren't Looking.” Politico, December 29. Available at www.politico.com/agenda/story/2017/ 12/29/138-trump-policy-changes-2017-0oo6o3.

Woolley, John T., and Gerhard Peters. 2017. "Do Presidential Memo Orders Substitute for Executive Orders? New Data.” Presidential Studies Quarterly 47 (2): 378-93 